\title{
Third Degree Atrioventricular Block in Children
}

\author{
Vinko Vrdoljak ${ }^{1}$ (D), Matej Šapina², Suzana Bitanga ${ }^{1}$, Matej Katavić ${ }^{1}$ \\ Department of Pediatrics, University Hospital Center Sestre Milosrdnice, Zagreb, Croatia \\ ${ }^{2}$ Department of Pediatrics, University Hospital Center Osijek, Osijek, Croatia
}

ABSTRACT:

Atrioventricular (AV) block is defined as a delay or interruption in the transmission of an impulse from the atria to the ventricles due to an anatomical or functional impairment in the conduction system. The conduction disturbance can be transient or permanent. In third degree AV block, also referred to as complete heart block, there is complete dissociation of the atrial and ventricular activity. Atrioventricular block is considered to be "congenital" when it occurs spontaneously in a fetus or young child. In children, the most common cause of permanent acquired complete AV block is surgery for congenital heart disease. Injury to fetal conduction tissues caused by transplacental exposure to maternal autoantibodies related to systemic lupus erythematosus or Sjogren's syndrome is responsible for 60 to 90 percent of cases of congenital CHB overall1-3. As many as 40 percent of cases of congenital CHB do not present until later in childhood (mean age five to six years). Only rarely do these patients ( 5 percent) have proven autoimmune etiology. The increased risk of sudden death is associated with the onset of deep bradycardia or ventricular arrhythmia. A routine electrocardiogram is sufficient to diagnose the disease. A 15-year-old girl has been examined at the emergency pediatric outpatient clinic of the University Hospital Centre "Sestre Milosrdnice" for recurrent episodes of presyncope. Physical examination revealed no major deviations other than bradycardia. Her vital signs were within the reference range, with the exception of a pulse of about 44 beats per minute. The electrocardiogram showed atrioventricular dissociation consistent with third degree atrioventricular block. The echocardiogram showed a structurally normal heart except for sinus bradycardia. The girl underwent permanent epicardial pacemaker implantation after which there were no symptoms.

OPEN ACCESS

Correspondence: Vinko Vrdoljak MD vinkov@yahoo.com orcid.org/0000-0002-7321-8057

This article was submitted to RAD CASA - Medical Sciences as the Case Report

Conflict of Interest Statement: The authors declare that the research was conducted in the absence of any commercial or financial relationships that could be construed as a potential conflict of interest.

Received: 11 November 2019 Accepted: 5 December 2019 Published: 17 December 2019

Citation:

Vrdoljak V, Šapina M, Bitanga S and Katavić M. Third Degree Atrioventricular Block in Children. RAD CASA- Medical Sciences, $540=48$ 49 (2019): 67-70. https:/dx.doi. org/10.21857/m3v76t6o3y

Copyright (C) 2019. Vrdoljak, Šapina, Bitanga and Katavić. This is an open-access article distributed under the terms of the Creative Commons Attribution License (CC BY). The use,

distribution or reproduction in other forums is permitted, provided the original author(s) and the copyright owners (s) are credited and that owners(s) are credited and that the original publication in this journal is cited, in accordance whit accepted adacemic practice. No use, distri-
bution or reproduction is permitted

which does not comply with these terms.
KEYWORDS: complete heart block, CHB, complete atrioventricular block, third degree atrioventricular block, congenital atrioventricular block, acquired atrioventrikular block, children, bradycardia

\section{SAŽETAK:}

\section{AtrioventrikUlarni BLOK SRCA TREĆEg STUPNJA u DJECE}

Atrioventrikularni (AV) blok je definiran kao kašnjenje ili prekid u prijenosu impulsa iz atrija u ventrikule zbog anatomskih ili funkcionalnih oštećenja u provodnom sustavu srca. Poremećaj provodljivosti može biti prolazan ili trajan. U AV bloku trećeg stupnja, koji se još naziva i kompletni srčani blok, dolazi do potpune disocijacije atrijske i ventrikularne aktivnosti. Atrioventrikularni blok se smatra "kongenitalnim" kada se pojavljuje spontano kod fetusa ili malog djeteta. Stečeni permanentni kompletni AV blok kod djece najčešće je posljedica kirurške korekcije prirođenih srčanih grešaka. Ozljeda fetalnog provodnog srčanog tkiva uzrokovana transplacentarnom izloženošću majčinim autoantitijelama povezanim sa sistemskim eritematoznim lupusom ili Sjogrenovim sindromom odgovorna je za 60 do 90 posto slučajeva kongenitalnog srčanog bloka1-3. Čak 40 posto slučajeva kongenitalnog srčanog bloka se javlja kasnije u djetinjstvu (prosječna dob od pet do šest godina). Od navedenih samo rijetki pacijenti (5 posto) imaju dokazanu autoimunu etiologiju. Povećan rizik iznenadne smrti se veže uz nastup duboke bradikardije ili ventrikulske aritmije. Za dijagnozu bolesti je dovoljan rutinski elektrokardiogram. Djevojčica od 15 godina je pregledana u hitnoj pedijatrijskoj ambulanti kliničkog bolničkog centra "Sestre Milosrdnice”, zbog ponavljajućih epizoda presinkopa. Tjelesnim pregledom se nije utvrdilo većih odstupanja, osim bradikardije. Njeni vitalni znakovi su bili unutar referentnog raspona, s izuzetkom pulsa koji je iznosio oko 44 otkucaja u minuti. Elektrokardiogram je pokazao atrioventrikularnu disocijaciju u skladu s atrioventrikularnim blokom trećeg stupnja. Ehokardiogram je izuzev sinusne bradikardije pokazao strukturno normalno srce. Djevojka je podvrgnuta ugradnji trajnog epikardijalnog pacmakera nakon čega više nije imala simptoma i tegoba u budućnosti.

KLJUČNE RIJEČI: kompletni srčani blok, kompletni atrioventrikularni blok, atrioventrikularni blok 3. stupnja, kongenitalni atrioventrikularni blok, stečeni atrioventrikularni blok, djeca, bradikardija 


\section{Case presentation}

A 15-year-old girl was referred to pediatric emergency department outpatient clinic of the University Hospital Centre "Sestre Milosrdnice" due to a recurrence of an episode of presyncope back in 3 days. For the past 11 months, there has been a daily feeling of shortness of breath. Three days before admission, she felt weak, flushed before her eyes, faded. The day before her admission, her eyes turned black again at school and she collapsed. There were no convulsive elements and she did not lose consciousness. After the examination, her vital signs were within the reference range. The heart action was bradycardic, a systolic murmur 1/6 heard over Erb's point was observed. The heart rate received was a bio variable and ranged from 42-60/ min. The electrocardiogram showed atrioventricular dissociation consistent with third degree atrioventricular block. A 24-h holter was made, recording an average rhythm of $44 / \mathrm{min}$ (daily $51 / \mathrm{min}$, night $36 / \mathrm{min}$ ). The minimum rhythm was reduced by $28 / \mathrm{min}$, the maximum by $109 / \mathrm{min}$. RR breaks of up to $3.5 \mathrm{~s}$ with rare isolated VES were noted. An echocardiographically discontinuation of the continuous interatrial septum at the level of the oval fossa $2 \mathrm{~mm}$ with an L-R flow of $1.06 \mathrm{~m} / \mathrm{s}$, hemodynamically insignificant. Spirometry was neat, salbutamol test negative. She had normal electrolytes, renal and liver function, full blood count and random blood sugar test results. Anti-SSA/Ro and anti-SSB/La, anti-double-stranded deoxyribonucleic acid (dsDNA), antinuclear antibodies (ANA) and antineutrophil cytoplasmic antibodies (ANCA) autoantibodies. were negative. There were no heart diseases in the family. The child underwent implantation of a permanent epicardial pacemaker after there were no symptoms.

\section{DisCUSSION}

The atrioventricular (AV) block is defined as the interruption or delay in the transfer of impulses from the atrium to the ventricles due to an anatomical or functional disorder in the conduction cardiac system. The atrioventricular block is considered "congenital" when it occurs spontaneously in a fetus or child. Congenital complete heart block (CHB) was first described in 1901 by Morquio, who also noted familial occurrence and association with Stokes-Adams attacks and death4. The presence of fetal bradycardia ( 40 to 80 beats per minute) as a manifestation of CHB was first noted in 1921 and is the initial sign of this disorder in many cases 5 . The incidence of congenital CHB is estimated from 1 in 15,000 to 1 and 22,000 newborns ${ }^{6,7}$. In children, the most common cause of permanently acquired complete AV block is surgery for congenital heart disease. Fetal conduction injury caused by transplacental transfer of maternal antibodies to patients with systemic lupus erythematosus or Sjogren's syndrome is thought to be responsible for 60-90 percent of the cause of congenital CHB. ${ }^{1-3}$ Among women with anti-Ro / SSA and / or anti-La / SSB antibodies, fetal / neonatal CHB occurs in approximately 2 percent of pregnancies ${ }^{8,9} .40$ percent of all congenital heart block cases are not clinically presented until later in childhood (average between 5 and 7 years) ${ }^{3}$. Only rarely do these patients ( 5 percent) have proven autoimmune etiology
3. The etiology of complete heart block in children includes the following: autoimmune diseases, structural abnormalities due to congenital heart defects (eg congenitally corrected transposition of large blood vessels, defects of endocardial pads), idiopathic familial congenital complete heart block, or the consequence of overfeeding myocardial myocardial surgery ${ }^{10}$. Congenitally impaired AV nodal function may also be observed in some simple cases of atrial septal defect among patients with Holt-Oram syndrome, an autosomal dominant disorder causing cardiac and upper-limb abnormalities that causes a mutation on the TBX5 gene ${ }^{11}$. The manifestation of congenital $\mathrm{CHB}$ varies depending on the age of presentation, causes, ventricular frequency, and ventricular function. Patients with autoimmune etiology present earlier than those with other causes of $\mathrm{CHB}^{12}$. Clinically, $\mathrm{CHB}$ is presented differently at a certain age. Regarding neonatal age, the primary presentation of infants with congenital heart block is a slow heart rate below 100 beats per minute. Such newborns may appear pale due to decreased cardiac output. Signs of congestive heart failure (eg, crackles on lung examination, elevated jugular venous pulsations, peripheral edema, etc) may also occur. First or second degree AV block found in infants at birth can progress to $\mathrm{CHB}$ and should be followed carefully ${ }^{13,-16} .40$ percent of patients with congenital $\mathrm{CHB}$ present later in childhood. The primary finding in these children is a slow heart rate with or without symptoms, including poorer effort tolerance, presyncope or syncope (Stokes-Adams seizures). Sudden death has also been rarely described $^{17-19}$.

A routine electrocardiogram is sufficient to diagnose the disease and echocardiography reveals an associated structural heart failure or cardiomyopathy. Holter monitoring and load tests assess the basal frequency of the downstream rhythm of the conductor and the possibility of its increase in various physiological requirements, tendency for deep bradycardia and arrhythmias. The therapeutic approach for prenatal diagnosed congenital CHB is largely expectant. If fetal hydrops or other signs of fetal distress develop, there is a possibility of early delivery or emergency pacing. If $\mathrm{CHB}$ diagnosed in utero is caused by transplacental transfer of maternal antibodies to patients with systemic lupus erythematosus or Sjogren's syndrome, corticosteroid therapy should be considered depending on the time of diagnosis. If the heart block is already complete and has been present for more than three weeks, it is considered that an attempt at reversing this complete heart block is futile, and therefore serial echocardiographic and obstetrical follow-up, but no therapy is recommended. If, however, the third degree heart block has been recently diagnosed, a therapeutic course of dexamethasone $4 \mathrm{mg}$. orally once a day for a period of six weeks may be attempted. For infants and children who are presented later, the therapeutic approach depends on the presence or absence of symptoms. Patients with adequate ventricular frequency and no symptoms may be followed, while symptomatic patients (usually those with a slower ventricular rhythm) need a permanent pacemaker ${ }^{20}$. Pacemaker implantation was recommended (class I) or felt to be reasonable (class IIa) for patients with congenital $\mathrm{CHB}$ and the following characteristics: 
symptomatic bradycardia or low cardiac output (class I), wide QRS escape rhythm, complex ventricular ectopy, or ventricular dysfunction (class I), infants with normal anatomy and a ventricular rate of less than 55 beats per minute (class I), infants with other structural congenital heart disease and a ventricular rate of less than 70 beats per minute (class I), children beyond the first year of life with an average heart rate of less than 50 beats per minute, or abrupt pauses two to three times the basic RR cycle length (class IIa). $\mathrm{CHB}$, which is presented prenatally, and is mainly due to maternal antibodies, is associated with a higher mortality rate re, $^{10,22}$. The outcome of patients diagnosed in the infant is better than the outcome of those diagnosed in utero. Children with $\mathrm{CHB}$ who are asymptomatic generally remain asymptomatic until later childhood, adolescence, or adulthood ${ }^{6,23}$. Prognosis is generally excellent among infants and those diagnosed later in childhood10. However, exercise limitation and even mortality in childhood are not negligible ${ }^{24-26}$. Even patients who have been asymptomatic throughout childhood are at increased risk of sudden death. In a review of 102 patients who were without symptoms through age 15, 27 (26 percent) had a subsequent syncopal episode, eight of which were fatal 18 . The ventricular rate tends to fall slowly with age ${ }^{18}$. To compensate for the slow heart rate, the heart enlarges to produce a higher stroke volume; in some cases, this may lead to voltage criteria for left ventricular enlargement and nonspecific ST-T wave changes ${ }^{27}$ as well as to heart failure ${ }^{28,29}$. In general, the prognosis of the following pacemaker implantation is excellent ${ }^{15,30,31}$. However, a significant number of patients ( 5 to 11 percent) develop heart failure over the long term, even if a pacemaker is inserted ${ }^{28,29}$.

\section{Conclusion}

The most common etiologies of $\mathrm{CHB}$ include the following: idiopathic familial congenital $\mathrm{CHB}$, autoimmune antibodies, structural heart abnormalities due to congenital heart disease (eg, congenitally corrected transposition of the great arteries, endocardial cushion defects), consequence of myocarditis or mechanical trauma from surgical or transcatheter interventions. Symptoms of children with complete AV block and structurally normal heart range from unbearable physical exertion, syncope to complete absence of symptoms. Treatment of patients with low cardiac output syndrome or at risk of sudden death is performed by installing a permanent electrostimulator. Despite its infrequency and life-threatening potential, patients with congenital complete heart block have an excellent survival rate with timely diagnosis and intervention.

\section{AUTHOR CONTRIBUTIONS:}

All authors listed have made a substantial, direct and intellectual contribution to the work, and approved it for publication.

\section{LITERATURE:}

1. Johansen AS, Herlin T. [Neonatal lupus syndrome. Association with complete congenital atrioventricular block]. Ugeskr Laeger 1998; 160:2521.

2. Ross BA. Congenital complete atrioventricular block. Pediatr Clin North Am 1990; 37:69.

3. Jaeggi ET, Hamilton RM, Silverman ED, et al. Outcome of children with fetal, neonatal or childhood diagnosis of isolated congenital atrioventricular block. A single institution's experience of 30 years. J Am Coll Cardiol 2002; 39:130.

4. Morquio, L. Sur une maladie infantile et familiale characterisée par des modifications permanentes du pouls, des attaques syncopales et epileptiforme et la mort subite. Arch Méd d'Enfants 1901; 4:467. 5. White, P, Eustis, R . Congenital heart block. Am J Dis Child 1921; 22:299.

6. Michaëlsson M, Engle MA. Congenital complete heart block: an international study of the natural history. Cardiovasc Clin 1972; 4:85.

7. Brito-Zerón P, Izmirly PM, Ramos-Casals M, et al. The clinical spectrum of autoimmune congenital heart block. Nat Rev Rheumatol 2015; 11:301.

8. Brucato A, Frassi M, Franceschini F, et al. Risk of congenital complete heart block in newborns of mothers with anti-Ro/SSA antibodies detected by counterimmunoelectrophoresis: a prospective study of 100 women. Arthritis Rheum 2001; 44:1832.

9. Buyon JP, Kim MY, Copel JA, Friedman DM. Anti-Ro/SSA antibodies and congenital heart block: necessary but not sufficient. Arthritis Rheum 2001; 44:1723.

10. Brito-Zerón P, Izmirly PM, Ramos-Casals M, et al. Autoimmune congenital heart block: complex and unusual situations. Lupus 2016; 25:116.
11. Mori AD, Bruneau BG. TBX5 mutations and congenital heart disease: Holt-Oram syndrome revealed. Curr Opin Cardiol 2004; 19:211.

12. Cruz RB, Viana VS, Nishioka SA, et al. Is isolated congenital heart block associated to neonatal lupus requiring pacemaker a distinct cardiac syndrome? Pacing Clin Electrophysiol 2004; 27:615. 13. Askanase AD, Friedman DM, Copel J, et al. Spectrum and progression of conduction abnormalities in infants born to mothers with anti-SSA/Ro-SSB/La antibodies. Lupus 2002; 11:145.

14. Nield LE, Silverman ED, Taylor GP, et al. Maternal anti-Ro and anti-La antibody-associated endocardial fibroelastosis. Circulation 2002; 105:843.

15. Eliasson H, Sonesson SE, Salomonsson S, et al. Outcome in young patients with isolated complete atrioventricular block and permanent pacemaker treatment: A nationwide study of 127 patients. Heart Rhythm 2015; 12:2278.

16. Waltuck J, Buyon JP. Autoantibody-associated congenital heart block: outcome in mothers and children. Ann Intern Med 1994; 120:544.

17. Sholler GF, Walsh EP. Congenital complete heart block in patients without anatomic cardiac defects. Am Heart J 1989; 118:1193. 18. Michaëlsson M, Jonzon A, Riesenfeld T. Isolated congenital complete atrioventricular block in adult life. A prospective study. Circulation 1995; 92:442.

19. Karpawich PP, Gillette PC, Garson A Jr, et al. Congenital complete atrioventricular block: clinical and electrophysiologic predictors of need for pacemaker insertion. Am J Cardiol 1981; 48:1098. 20. Kusumoto FM, Schoenfeld MH, Barrett C, et al. 2018 ACC/ AHA/HRS Guideline on the Evaluation and Management of Patients 
With Bradycardia and Cardiac Conduction Delay: A Report of the American College of Cardiology/American Heart Association Task Force on Clinical Practice Guidelines and the Heart Rhythm Society. J Am Coll Cardiol 2019; 74:e51.

21. Izmirly PM, Saxena A, Kim MY, et al. Maternal and fetal factors associated with mortality and morbidity in a multi-racial/ethnic registry of anti-SSA/Ro-associated cardiac neonatal lupus. Circulation 2011; 124:1927.

22. Levesque K, Morel N, Maltret A, et al. Description of 214 cases of autoimmune congenital heart block: Results of the French neonatal lupus syndrome. Autoimmun Rev 2015; 14:1154.

23. McHenry MM. Factors influencing longevity in adults with congenital complete heart block. Am J Cardiol 1972; 29:416.

24. Dewey RC, Capeless MA, Levy AM. Use of ambulatory electrocardiographic monitoring to identify high-risk patients with congenital complete heart block. N Engl J Med 1987; 316:835.

25. Reybrouck T, Vanden Eynde B, Dumoulin M, Van der Hauwaert LG. Cardiorespiratory response to exercise in congenital complete atrioventricular block. Am J Cardiol 1989; 64:896.ž

26. Motonaga KS, Punn R, Axelrod DM, et al. Diminished exercise capacity and chronotropic incompetence in pediatric patients with congenital complete heart block and chronic right ventricular pacing. Heart Rhythm 2015; 12:560.

27. Kertesz NJ, Friedman RA, Colan SD, et al. Left ventricular mechanics and geometry in patients with congenital complete atrioventricular block. Circulation 1997; 96:3430.

28. Moak JP, Barron KS, Hougen TJ, et al. Congenital heart block: development of late-onset cardiomyopathy, a previously underappreciated sequela. J Am Coll Cardiol 2001; 37:238.

29. Udink ten Cate FE, Breur JM, Cohen MI, et al. Dilated cardiomyopathy in isolated congenital complete atrioventricular block: early and long-term risk in children. J Am Coll Cardiol 2001; 37:1129.

30. Pordon CM, Moodie DS. Adults with congenital complete heart block: 25-year follow-up. Cleve Clin J Med 1992; 59:587.

31. Groves AM, Allan LD, Rosenthal E. Outcome of isolated congenital complete heart block diagnosed in utero. Heart 1996; 75:190. 